\title{
INVESTICINIO PORTFELIO FORMAVIMAS GLOBALIOJE AKCIJŲ RINKOJE REMIANTIS BLACK - LITTERMAN METODU
}

\author{
Laurynas MIKULIS*, Renaldas VILKANCAS \\ Vilniaus Gedimino technikos universitetas, Verslo vadybos fakultetas, \\ Finansu inžinerijos katedra, Saulètekio al. 11, LT-10223, Vilnius, Lietuva \\ "El.paštas laurynas.mikulis@stud.vgtu.lt
}

\begin{abstract}
Santrauka. Straipsnyje yra analizuojama Black - Litterman optimalaus portfelio teorija ir jos praktinio pritaikymo galimybės. Remiantis atlikta mokslinès literatūros analize, apibrèžiamas Black - Litterman modelis, palyginamas su H. Markowitz teorija, išskiriami pagrindiniai BL teorijos pranašumai ir trūkumai. Pasitelkiant analitinį hierarchinị procesą (AHP) nustatomi pasirinktų santykinių finansinių rodiklių svoriai. Atliekant daugiakriterinį vertinimą TOPSIS metodu, iš dešimties didžiausių pagal apyvartą įmonių „OMX Nordic 40“ indekse: „Volvo“, „Assa“, „Sandvik“, „Neste“, „Investor“, „SEB“, „Atlas“, „Novo Nordisk“, „Vestas wind systems“" ir „Nordea“, išrenkamos penkios perspektyviausios ịmonių akcijos ị kurias bus investuojama. Remiantis gautais rezultatais, suformuojamas optimalus investicinis portfelis pagal Black - Litterman ir H. Markowitz modelius, ịvertinami sudarytų portfelių rezultatai ir jie palyginami tarpusavyje.
\end{abstract}

Reikšminiai žodžiai: portfelio optimizavimas, Black - Litterman, investuotojo požiūris, „OMX Nordic 40“, TOPSIS, AHP, H. Markowitz.

\section{İvadas}

Remiantis Lietuvos statistikos departamento duomenimis, per dešimties metų laikotarpi nuo 2008 iki 2018 metų, vidutinès mènesinès disponuojamos pajamos, tenkančios vienam namų ūkio nariui padidèjo apytiksliai 1,76 kartus. Didejjant laisvoms lèšoms, gyventojams atsiranda poreikis ieškoti būdų, kaip šias lèšas ,idarbinti“, siekiant dar didesnès naudos. Vienas populiariausių būdų yra investavimas. Investuotojo tikslas gauti maksimalią grąžą, esant minimaliam rizikos lygiui. Šiam tikslui pasiekti dažniausiai sudaromas vertybinių popierių portfeli. Sudarant vertybinių popierių portfelį yra stengiamasi pasirinkti tarpusavyje derančius aktyvus, taip siekiant padidinti grąžą arba sumažinti riziką. Vertybinius popierius galima rinktis iš daugybès skirtingų variantų, esančiu skirtingose finansų rinkose visame pasaulyje. Globalizacijos veiksniu paveiktos rinkos, tampa labiau integruotos, lengviau prieinamos ir operatyvios, todèl investavimo procesas tampa paprastesnis ir efektyvesnis. Tačiau atsirandant naujoms galimybèms, didèja investavimo rizikos.

Finansų rinkose yra begalè greitai kintančios informacijos, kurią sunku sekti ir prognozuoti, todèl sprendimams priimti yra naudojami ịvairūs vertybinių popierių analizès metodai. Tačiau vien vertybinių popierių analizès neužtenka, todèl siekiant sumažinti riziką ar padidinti laukiamą grąžą sudaromas investicinis portfelis. Remiantis įvairiomis analizėmis ir teorijomis yra derinami vertybiniai popieriai, siekiant sukuti optimalu portfeli, kuris atitiktų kiekvieno investuotojo asmeninius lūkesčius. Tačiau tiek vertybinių popierių analizès metodikos, tiek portfelio optimizavimo teorijos turi tam tikrų ribotumų, todèl investuotojams kyla poreikis ieškoti naujų, efektyvesnių ir mažiau mokslinèje literatūroje nagrinètų metodikų, kuriomis remiantis būtų galima sudaryta efektyvesnị investicinị portfelį.

Mokslinio tyrimo objektas - Black - Litterman investicinio portfelio teorija. Ši teorija pasirinkta todèl, nes ji yra mažai tyrinèta mokslinèje literatūroje.

Tyrimo tikslas - Remiantis turimais rezultatais, suformuoti optimalų investicinį portfelį Black - Litterman metodu, palyginti sudarytą portfelį su H. Markowitz portfeliu. Tikslui pasiekti iškelti uždaviniai:

- Apibrèžti Black - Litterman investicinio portfelio teorijos privalumus ir trūkumus;

- Naudojant analitinį hierarchinį procesą, nustatyti santykinių finansinių rodiklių svorius;

- Atlikti daugiakriterinị ịmonių akcijų vertinimą TOPSIS metodu;

- Remiantis Black - Litterman teorija sudaryti optimalų investicinį portfelį;

- Remiantis H. Markowitz teorija sudaryti optimalų investicini portfeli;

- Palyginti sudarytus portfelius tarpusavyje. 
Tyrimo metodika: užsienio ir lietuvių autorių mokslinès literatūros apžvalga ir analizè, daugiakriterinis vertinimas, analitinis hierarchinis procesas (AHP), Black - Litterman teorija.

\section{Black - Litterman optimalaus portfolio teorija}

Investuotojai siekdami sudaryti sèkmingą investicinį portfelį, pirmiausia turi apsibrěžti kokius investicinius instrumentus ir kokiomis dalimis juos reikètų sukomponuoti, kad portfelio grąža būtų maksimali, o rizika minimali. Šị klausimą investuotojai pradèjo spręsti dar 1950 metais, tuomet buvo pradèta ieškoti idealiausio varianto tarp grąžos maksimizavimo ir rizikos minimizavimo ( $\mathrm{Li}$ et al., 2019). Vienos pirmuju - moderniosios investicinio portfelio teorijos pradininku tapo Harry Markowitz, kuris XX a. pradžioje, apibrèžè optimalaus portfolio, diversifikacijos sąvokas, pradèjo sieti riziką su grąža ir ị portfeli pradèjo žiūrèti, kaip ị vientisą vertybinių popierių darinị (Zakarkaitè ir Filipavičius, 2017). Šios teorijos pagrindu buvo sukurta ne viena nauja teorija, kurios tikslas šalinti moderniojo investicinio portfelio ribotumus. Viena iš tokių teorijų tapo investicinio banko „Goldman Sachs“ analitikų: Fisher Black ir Robert Litterman, 1991 metais sukurta Black - Litterman portfelio optimizavimo teorija (Jurkonyte ir Paužuolis, 2015).

Black - Litterman teorija, tai H. Markowitz optimalaus portfelio teorija paremtas, sudètingas matematinis, statistinis modelis, sujungiantis vertybinių popierių kainų istorinius duomenis su investuotojo individualiu požiūriu (A. Palczewski ir J. Palczewski, 2019). Black - Litterman teorija buvo sukurta siekiant patobulinti H. Markowitz (Huang ir Yang, 2020). Markowitz modelis kritikuojamas dèl pakankamai nestabilių portfelio svorių, kuriuos laikui bėgant reikia perskaičiuoti, dažni portfelio perskaičiavimai ir pakeitimai generuoja papildomus kaštus (Trichilli et al., 2020). Taip pat, H. Markowitz optimalaus portfolio teorija dažnai kritikuojama dèl to, jog investicinis portfelis formuojamas remiantis bendromis investuotojų elgsenos prielaidomis ir praeities duomenimis, kurie gali netiksliai atspindèti būsimą tendenciją (Pang ir Karan, 2018). Didžiausias teorijas trūkumas yra, tas jog modelis yra labia jautrus grąžų pokyčiams, kurios gali iškreipti įmonių akcijų sudètį, sudarytame investiciniame portfelyje (Silva et al., 2017). F. Black ir R. Litterman ị savo sukurtą portfelio optimizavimo teoriją įtraukè individualią investuotojo nuomonę, kuri padeda patikimiau ịvertinti i portfelị ịtraukiamus investicinius instrumentus (Gharakhani ir Sadjadi, 2013). BL modelyje atsiranda naujas pelningumo matas - laukiamas, perteklinis pelningumas, kuris yra siejamas su investuotojo lūkesčiais, o tuo tarpu, modernioje portfelio teorijoje naudojamas minimalus investuotojui priimtinas pelningumas, kuris gaunamas ịvertinimus finansinius tikslus (Jurkonyte ir Paužuolis, 2015). BL modelyje atsiranda naujas rizikos matas - investuotojo polinkis ị riziką, kuris padeda ịvertinti investuotojo pasiryžimą rizikuoti (Huang ir Yang, 2020). Formuojant portfeli pagal Markowitz teoriją, pasitelkiami istoriniai vertybinių popierių kainų pokyčiai, o tuo tarpu, taikant BL modeli apjungiami istoriniai duomenys su subjektyviu investuotojo požiūriu, kuris padeda ịvertinti vertybinius popierius neatsižvelgiant tik i jų istorius duomenis, todèl tiksliau galima nuspèti būsimas kitimo tendencijas (Cayirli, 2019). Black - Litterman optimalaus portfelio teorija paremta šiomis pagrindinèmis prielaidomis (Idzorek, 2007):

- Rinkos ir investuotojų požiūris ị finansinių instrumentų grąžą yra normaliai pasiskirstęs;

- Rinkoje rizika nerizikingų investicinių priemonių;

- Investicinių instrumentų kiekis yra fiksuotas;

- Investuotojai elgiasi racionaliai, siekdami maksimizuoti gaunamą naudą;

- Investuotojai yra vengiantys rizikos, todèl stengiasi minimizuoti riziką ir maksimizuoti grąžą;

- Investuotojų portfelis yra ịvertintas pagal pavyzdinị portfelį;

- Investuotojai gali vertinti tik tuos vertybinius popierius, apie kuriuos turi nuomonę;

- Investuotojai negali būti visiškai tikri apie savo nuomonę;

- Investuotojai gali nustatyti savo pasitikèjimo lygị.

Black - Litterman teorija, taip pat, vadovaujasi prielaida, jog efektyvios rinkos hipoteze, kuri teigia, jog visa žinoma informacija atsispindi vertybinių popierių kainose yra neteisinga. Remiantis šia prielaida tikima, kad ne visos vertybinių popierių kainos yra teisingos, todèl investuotojai pasitelkę savo nuomonę gali atrasti pervertintus arba per mažai ịvertintus vertybinius popierius, kuriuos gali ịtraukti ị investicinị portfelị (Norell ir Dove, 2016).

BL modelis išsiskiria iš kitų portfelio optimizavimo teorijų dviem pagrindiniai aspektais (Vilkancas, 2017):

- Laukiamas pelningumas nustatomas naudojant kapitalo įkainojimo modelị (CAPM);

- Modelis pateikia naują metodiką, kuria remiantis galima įvertinti investuotojo požiūrị ir jị susieti su pradine investuotojo turima informacija.

Nors Black - Litterman investicinio portfelio optimizavimo teorija yra žingsnis ị priekį, tačiau nepaisant naujo, universalesnio požiūrio, kuris leidžia investuotojai i modelị įtraukti ir savo nuomonę apie investicinị instrumentą, šis modelis taip pat turi trūkumų ir atsiradusių naujų problemų. Viena iš jų yra ta, jog modelis naudoja keletą matų: $\tau$ ir $\delta$, kuriuos yra sunku ịvertinti (Vilkancas, 2017). Pagal F. Black ir T. Litterman $\tau$ reikšmé turètų būti artima nuliui, tačiau pagal kitų mokslininkų nuomonę šio mato reikšmè turètų būti artima vienetui. Parametras $\delta$ gali būti vertinamas kaip perteklinè rinkos grąža arba kaip dispersija ar rizikos vengimo konstanta (Vilkancas, 2017). Pagrindinis šio modelio trūkumas yra tas, jog jis vadovaujasi prielaidą, kad grąža yra normaliai pasiskirsčiusi, nors paprastai rinkos sąlygomis, to nèra (Polovenko, 2017). 


\section{Daugiakriterinis įmonių akcijų vertinimas}

Tyrimo metu yra atrenkamos perspektyviausios imonių akcijos investiciniam portfeliui formuoti. Atrankai pasirinktos dešimt pagal kapitalizaciją didžiausių ịmonių akcijų iš „OMX Nordic 40“ indekso: „Volvo“, „Assa“, „Sandvik“, „Neste“, „Investor“, „SEB““, „Atlas“, „Novo Nordisk“, „Vestas wind systems“ ir „Nordea“. Pasirinktos imoniu akcijos buvo vertinamos pagal pasirinktus santykinius finansinius rodiklius: akcijos kainos ir pelno, tenkančio akcijai, santyki (P/E), nuosavo kapitalo grąžą (ROE), Pajamų augimą (5 metų laikotarpiu), skolinto ir nuosavo kapitalo santykị ir dividendini pajamingumą (Brazauskas, 2014). Tyrimui atlikti naudojami paskutiniai 2018 metais paskelbti ịmonių finansiniai rodikliai. Atrankai atlikti pasirinktas daugiakriterinis vertinimas TOPSIS metodu, finansinių rodiklių reikšmingumui ivvertinti pasirinktas analitinis hierarchinis (AHP) metodas. TOPSIS metodas pasirinktas dèl paprasto naudojimo ir funkcionalumo vertinant skirtingais matais išreikštus kriterijus. AHP metodas pasirinktas dèl efektyvios kriterijų palyginimo metodikos.

Pirmiausia siekiant atlikti daugiakriterinį vertinimą būtina nustatyti pasirinktų rodiklių reikšmingumą, tam bus naudojamas AHP metodas. Šis sprendimų prièmimu metodas dažniausiai naudojamas: vertinimo kriteriju hierarchijos sudarymui, santykinių svoriu priskyrimui kriterijams, alternatyvų palyginimui ir reitingui sudaryti (Kolios et al., 2016). Atliekant santykinių svorių nustatymą, pirmiausia, pasirinkti ekspertai užpildo porinio palyginimo anketą, remdamiesi T. L. Saaty ịverčių vertinimo sistema (Wang et al., 2019). Gauti rezultatai susisteminami ir normalizuojami, siekiant suvienodinti kriterijų reikšmes.

$$
X_{i j}=\frac{c_{i j}}{\sum_{i, j=1}^{n} c_{i j}},
$$

čia: $X_{i j}$ - normalizuota reikšmé; $c_{i j}$ - kriterijaus reikšmè.

Nustačius kriterijų reikšmingumą porinio palyginimo metodu, būtina apskaičiuoti suderinamumo lygị (CR), kadangi gali atsirasti ekspertų nuomoniu nesuderinamumo problema. Jeigu gautas rezultatas yra iki 10 proc., ekspertų nuomonès yra suderintos, jeigu CR yra didesnis už 10 proc. ekspertų nuomonès yra nesuderinamos (Rajak ir Shaw, 2019). Norint apskaičiuoti CR, pirmiausia reikia rasti patikimumo indeksą (CI), norint ji apskaičiuoti reikia rasti lambdą reikšmę. Lambdą reikšmę apskaičiuojame pagal formulę (Rajak ir Shaw, 2019):

$$
\lambda=\frac{C v_{i j}}{W_{i j}},
$$

čia: $\lambda$ - lambda reikšmé; $C v_{i j}$ - normalizuota matrica su svoriais; $W_{i j}$ - reikšmių svoriai.

Normalizuotą matricą su svoriais apskaičiuojame pagal formulę (Khan et al., 2019):

$$
C v_{i j}=\left[\begin{array}{ccc}
C_{11} & \cdots & C 1 n \\
\vdots & \ddots & \vdots \\
C n 1 & \ldots & C n m
\end{array}\right] \times \begin{gathered}
W_{11} \\
\vdots \\
W_{1 n}
\end{gathered}
$$

čia: $C v_{i j}$ - normalizuota matrica su svoriais; $C n m$ - normalizuotos matrices reikšmė; $W_{1 n}$-kriterijų svoris.

Turint Lambda reikšmes ir kriterijų kiekį, galima apskaičiuoti suderinamumo indeksą (CI) (Mannan ir Haleem, 2017).

$$
C I=\frac{\lambda_{\max }-n}{n-1},
$$

čia: $C I$ - suderinamumo indeksas; $\lambda_{\max }$-vidutinè lambda reikšmé; $n$-kriterijų skaičius.

Paskutinị suderinamumo lygio formulès nežinomaji - atsitiktinị suderinamumo indeksą (RI), surandame pagal T. L. Saaty sudarytą indeksų reikšmių lentelę, ji pasirenkame atsižvelgiant ị kriterijų kiekị (Rajak ir Shaw, 2019) (žr. 1 lentelę).

1 lentelè. Atsitiktinis suderinamumo indekso (RI) reikšmès (sudaryta autoriaus, Rajak ir Shaw, 2019)

\begin{tabular}{|c|c|c|c|c|c|c|}
\hline $\mathrm{N}$ & 1 & 2 & 3 & 4 & 5 & 6 \\
\hline $\mathrm{IR}$ & 0 & 0 & 0,58 & 0,9 & 1,12 & 1,24 \\
\hline
\end{tabular}

Apskaičiavę visus nežinomuosius, galime rasti suderinamumo lygi (CR) (Solangi et al., 2019).

$$
C R=\frac{C I}{R I}
$$

čia: CR - suderinamumo lygis; CI - suderinamumo indeksas; RI - atsitiktinis suderinamumo indeksas. 
Atlikus kriterijų santykinių svorių nustatymą analitiniu hierarchiniu procesu (AHP), gaunam reikšmes, kurios bus naudojamos daugiakriteriniame vertinime TOPSIS metodu (žr. 2 lentelę).

2 lentelè. Kriterijų svoriai (sudaryta autoriaus)

\begin{tabular}{|l|c|}
\hline \multicolumn{1}{|c|}{ Kriterijus } & Svoris \\
\hline Akcijos kainos ir pelno, tenkančio akcijai, santykis (P/E) & 0,495 \\
\hline Nuosavo kapitalo grąža (ROE) & 0,168 \\
\hline Pajamų augimas (5m) & 0,245 \\
\hline Skolinto ir nuosavo kapitalo santykis & 0,060 \\
\hline Dividendinis pajamingumas & 0,033 \\
\hline
\end{tabular}

Apskaičiavus CR, gauname, jog jo reikšmè yra lygi 0,091 arba 9,06 proc., todèl galima daryti prielaidą, jog ekspertų, kurie dalyvavo pildant porinio palyginimo anketą nuomonès yra suderintos, todèl gautus santykinių finansinių rodiklių svorius galime naudoti TOPSIS metode.

Atlikus pasirinktų kriterijų reikšmingumo vertinimą ir patikrinus ekspertų nuomonių suderinamumą, atliekamas daugiakriterinis vertinimas TOPSIS metodu, kurio pagrindinis tikslas rasti alternatyvą, kuri yra arčiausiai „,idealaus geriausio“ varianto (Dash et al., 2019). Perspektyviausių įmonių akcijos bus atrenkamos iš dešimties didžiausių pagal kapitalizaciją ịmonių iš „OMX Nordic 40“ indekso. İmonès bus vertinamos atsižvelgiant i pasirinktus santykinius finansinius rodiklius.

Atliekant daugiakriterinị vertinimą TOPSIS metodu, pirmiausia apsibrež̌iami vertinimo rodikliai ir jų kriterijai. Pasirinkus rodiklius ir vertinimo kriterijus sudaroma sprendimo matrica (Dash et al., 2019). Kadangi rodiklių reikšmės išreikštos ne vienodais matais, reikia sudarytą sprendimų matricą normalizuoti. Šis žingsnis atliekamas naudojant formulę (Aires ir Ferreira, 2019):

$$
r_{i j}^{\prime}=\frac{x_{i j}}{\sqrt{\sum_{i=1}^{m} x_{i j}^{2}}},
$$

čia: $r_{i j}^{\prime}$ - normalizuota matrica; $x_{i j}$ - rodiklių reikšmè.

Atlikus matricos normalizavimą, toliau nusprendžiama, kurie kriterijai maksimizuoja reikšmes, kurie minimizuoja. Kriterijai, kurių didžiausios reikšmès yra geriausios, pavyzdžiui, nuosavo kapitalo grąža, pajamų augimas, dividendinis pajamingumas yra maksimizuojantys. Kriterijai, kurių mažiausios reikšmès yra geriausias, pavyzdžiui, akcijos kainos ir pelno, tenkančio akcijai santykis, skolinto ir nuosavo kapitalo santykis yra minimizuojantys. Vienas iš svarbiausių etapų yra nustatyti kiekvieno kriterijaus reikšmingą. Tikslingiausia svorių nustatymui naudoti analitinį hierarchini procesą (AHP).

Nustačius kiekvieno kriterijaus reikšmingumo lygi, apskaičiuojama svorių matrica, kuri gaunama sudauginus normalizuotą matricą su anksčiau nustatytais kriterijaus svoriais (Biswas et al., 2015):

$$
v_{i j}=w_{j} r_{i j}^{\prime}
$$

čia: $v_{i j}$-svertinė normalizuota matrica; $w_{j}$ - kriterijaus svoris; $r_{i j}^{\prime}$ - normalizuota matrica.

Apskaičiavus svertinę normalizuota matricą, toliau nustatoma, kurie rodikliai yra maksimizuojantys, kurie minimizuojantys ir nustatomi ,idealiai geriausiais“ ir „,neigiamai idealus“ variantas. „Idealiai geriausias“" nustatomas pagal formulę (Simanavičienè ir Cibulskaitè, 2015):

$$
\left.\left.A^{+=\left\{\left(\max v_{i j} \mid j \in J\right),\left(\min v_{i j} \vee j \in J\right.\right.}\right) \vee i=1, m\right\}=
$$

čia: $A^{+}-$,idealus geriausias“"variantas; $\operatorname{maxv}_{i j}$ - geriausia rodiklio reikšmè.

Analogiškai nustatomi „Neigiamai idealus“ variantas, pagal formulę (Chen, 2019):

$$
A^{-=\left\{\left(\min v_{i j} \mid j \in J\right),\left(\max v_{i j} \vee j \in J^{\prime}\right) \vee i=1, m\right\}=}
$$

čia: $A^{-}-$,neigiamai idealus“ variantas; $\min v_{i j}$ - blogiausia rodiklio reikšmè.

Nustatę ,idealius geriausiu“ ir „neigiamai idealius“ variantus, toliau yra apskaičiuojamas atstumas iki lyginamojo „,idealiai geriausio“, $A^{+}$varianto Euklido erdvèje (Palczewski ir Sałabun, 2019):

$$
L_{i}^{+=\sqrt{\sum_{j=1}^{n}},}
$$


čia: $L_{i}^{+}$- atstumas iki „,idealiai geriausio“ varianto; $v_{i j}$ - svertinè normalizuota matrica; $a_{j}^{+}$- rodiklio ,idealus geriausias" variantas. 2019):

Panašiu principu toliau skaičiuojamas atstumas nuo „neigiamai idealaus“ varianto $A^{-}$(Palczewski ir Sałabun,

$$
L_{i}=\sqrt{\sum_{j=1}^{n}}
$$

čia: $L_{i}^{-}$- atstumas iki „neigiamai idealaus“ varianto; $v_{i j}$-svertinė normalizuota matrica; $a_{j}^{-}$- rodiklio ,neigiamai idealus geriausias" variantas.

Paskutiniame TOPSIS metodo etape, nustatomas kiekvieno varianto santykinis atstumas iki ,idealaus geriausio“ varianto (Simanavičienė ir Cibulskaite, 2015):

$$
K_{1}=\frac{L_{i}^{-}}{L_{i}^{++L_{i}^{-}},},
$$

čia: $K_{1}$ - santykinis atstumas iki ,idealaus geriausio“ varianto; $L_{i}^{-}$- atstumas iki „neigiamai idealaus“ varianto; $L_{i}^{+}$- atstumas iki ,teigiamai idealaus“" varianto.

Atlikę skaičiavimus sudarome prioritetinę eilutę, pirma vieta atitenka įmonės akcijoms, kurios $K_{1}$ reikšmė yra didžiausia, toliau eina, antras pasirinkimas, kurio $K_{1}$ reikšmė yra antra geriausia ir taip toliau, kol sureitinguojami visi variantai. Gauti rezultatai ir įmonių reitingai pateikiami apačioje (žr. 3 lentelę):

3 lentelè. Daugiakriterinio vertinimo TOPSIS metodu rezultatai (sudaryta autoriaus)

\begin{tabular}{|l|c|c|c|c|}
\hline \multicolumn{1}{|c|}{ Imonès } & $L^{+}$ & $L^{-}$ & $K_{1}$ & Vieta \\
\hline Vestas wind systems & 0,193 & 0,035 & 0,115 & 0,001 \\
\hline Assa & 0,207 & 0,028 & 0,125 & 0,002 \\
\hline Atlas & 0,200 & 0,066 & 0,028 & 0,002 \\
\hline Investor & 0,132 & 0,010 & $-0,104$ & 0,001 \\
\hline Neste & 0,181 & 0,035 & $-0,033$ & 0,001 \\
\hline Sandvik & 0,068 & 0,040 & 0,030 & 0,002 \\
\hline SEB & 0,062 & 0,026 & $-0,020$ & 0,052 \\
\hline Nordea & 0,170 & 0,007 & $-0,021$ & 0,028 \\
\hline Novo Nordisk & 0,178 & 0,129 & 0,100 & 0,000 \\
\hline Volvo & 0,073 & 0,041 & 0,080 & 0,004 \\
\hline
\end{tabular}

Remiantis 3 lentelèje gautais TOPSIS vertinimo rezultatais, iš dešimties pasirinktų įmonių atrenkamos penkios, kurių $K_{1}$ reikšmė yra didžiausia, daroma prielaida, jog šių įmonių akcijos yra perspektyviausios. Pasirinktos akcijos: „Volvo“, „Novo nordisk“, „Sandvik“, „Vestas wind system“ ir „Assa“, kuriomis bus formuojamas investicinis portfelis.

\section{Optimalaus portfelio formavimas Black - Litterman metodu}

Pirmoje tyrimo dalyje, įvertinus finansinių rodiklių reikšmingumą, atlikus daugiakriterinį vertinimą, atrinktos penkios imonių akcijos: „Volvo“, „Novo nordisk“, „Sandvik“, „Vestas wind system“ ir „Assa“, kuriomis bus formuojamas optimalus investicinis portfelis, remiantis Black - Litterman modeliu. Formuojant portfeli BL metodu, surenkami duomenys apie atrinktų ịmonių akcijų ir „OMX Nordic 40“ indekso grąžas 2015-2020 metų laikotarpiu, nerizikingai palūkanų normai apibrěžti pasirenkame Jungtinių Amerikos Valstijų dešimties metų obligacijos pelningumą. Ši obligacija buvo pasirinkta dèl pastovumo ir tvirtumo. Black - Litterman modelis apskaičiuojamas pagal formulę (Subekti et al., 2019):

$$
E(R)=\left[\left(\tau \sum\right)^{-1}+P^{\prime} \Omega^{-1} P\right]^{-1}\left[\left(\tau \sum\right)^{-1} \Pi+P^{T} \Omega^{-1} Q\right],
$$

čia: $E(R)$ - naujas kombinuotas grąžos vektorius; $\tau$ - konstanta; $\Sigma$ - perteklinès grąžos kovariacijos matrica; $\Pi$ - numanomos perteklinès grąžos vektorus; $\mathrm{P}$ - sąsajos matrica; $\Omega$ - nuomonès patikimumo matrica; $\mathrm{Q}$ grąžų prognozės matrica. 
Remiantis pateikta BL metodika, pirmiausia randamas numanomos perteklinės grąžos vektorius (Bayram et al., 2018).

$$
\prod \delta \sum w_{m k t},
$$

čia: $\prod$ - numanomos perteklinės grąžos vektorus; $\delta$ - rinkos rizikos vengimo koeficientas; $w_{m k t}-$ rinkos kapitalizacijos svoris; $\sum$ - perteklinès grąžos kovariacijos matrica.

Siekiant rasti numanomos perteklinės grąžos vektorių, reikia apskaičiuoti: rinkos rizikos vengimo koeficientą, perteklinès grąžos kovariaciją ir rinkos kapitalizacijos svorius. Rinkos rizikos vengimo koeficientas parodo, normą, kurią pasiekus investuotojas atsisako didesnès tikètinos grąžos dẻl mažesnio nuokrypio (Allaj, 2017).

$$
\delta=\frac{E(r)-r_{f}}{\sigma^{2}},
$$

čia: $\delta$ - rinkos rizikos vengimo koeficientas; $E(r)$ - rinkos portfelio grąža; $r_{f}$ - rinkos vertybinių popierių grąža; $\sigma^{2}-$ rinkos portfolio dispersija.

Turint laukiamą perteklinę grąžą galima apskaičiuoti aktyvų kovariaciją, kuri parodo įmonių akcijų priklausomybę viena nuo kitos. Kovariacijai apskaičiuoti naudojamas „Excel“ programoje esantys „,data analysis“ įrankis.

Toliau vertinamas individualus investuotojo požiūris į vertybinių popierių grąžas ir sudaroma požiūrių matrica (Bayram et al., 2018).

$$
Q=\left[\begin{array}{c}
q_{1} \\
q_{k}
\end{array}\right] ; P=\left[\begin{array}{ccc}
p_{1,1} & \cdots & p_{1, n} \\
\vdots & \ddots & \vdots \\
p_{k, 1} & \cdots & p_{k, n}
\end{array}\right] ; \quad \Omega=\left[\begin{array}{ccc}
w_{1} & 0 & 0 \\
0 & \ddots & 0 \\
0 & 0 & w_{k}
\end{array}\right],
$$

čia: $Q$ - grąžų prognozès matrica; $P$ - sąsajos matrica; $\Omega$ - nuomonès patikimumo matrica.

Investuotojo individualaus požiūrio įtraukiamas formuojant portfeli yra išskirtinè BL modelio savybè, kuri padeda prognozuoti vertybinių popierių kainų pokyčius neatsižvelgiant tik ị istorinius duomenis, kurie dažnai gali neparodyti tikrosios tendencijos. Atsižvelgiant i pranešimus spaudoje ir veiklos rezultatus prognozuojami akcijų kainų pokyčiai:

- İmonès „Novo nordisk“ akcijos nukris 0,125 proc. lyginant su „Volvo“ imonès akcijomis;

- İmonès „Assa“ akcijos nukris 0,15 proc. lyginant su „Vestas win system“ imonès akcijomis;

- İmonès „Vestas wind system“ akcijos pakils 0,1 proc. lyginant su „Sandvik“ įmonès akcijomis.

Apskaičiavus visus BL formulès nežinomuosius: perteklinès grąžos kovariacijos matricą, numanomos perteklinès grąžos vektorių, investuotojo požiūrio sąsajos matricą, nuomonès patikimumo matricą ir grąžų prognozès matricą, randamas naujas, kombinuotas grąžos vektorius ir įmonių akcijų laukiamas pelningumas ịtraukus investuotojo požiūrị (žr. 1 paveikslą).

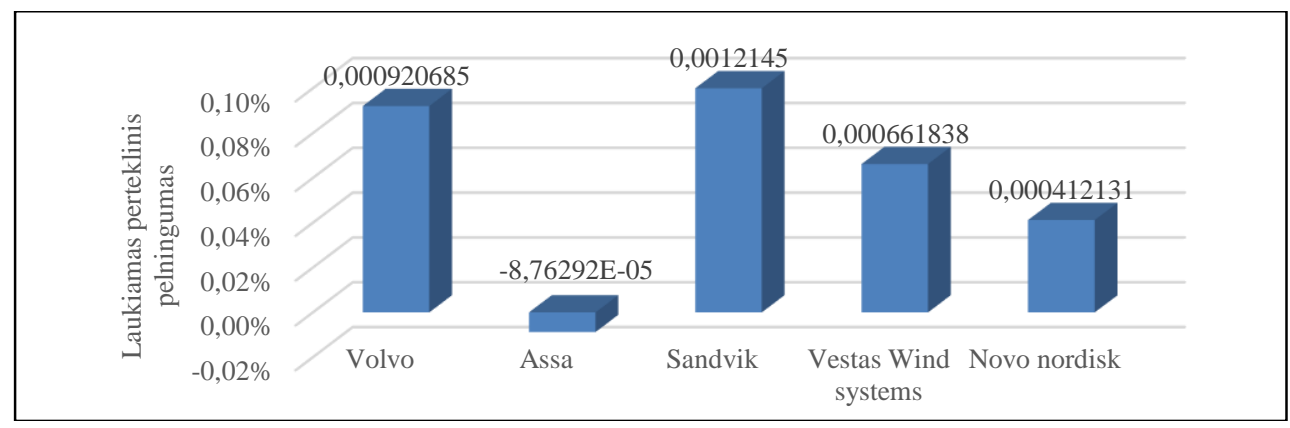

1 paveikslas. Laukiamos perteklinės įmonių akcijų grąžos (sudaryta autoriaus)

Remiantis 1 paveiksle gautais rezultatais, didžiausia perteklinè grąža numanoma įmonių: „Volvo“ $(0,09$ proc. $)$ ir „Sandvik“ (0,12 proc.), mažiausia „Assa“ (-0,01 proc.) ir „Novo nordisk“ (0,04 proc.) akcijoms.

Remiantis gautais įmonių akcijų perteklinès grąžos, standartinio nuokrypio rezultatais, naudojant „Excel“ programos ,Solver“ ịrankị, suformuojamas optimalus investicinis portfelis (žr. 2 paveikslą). 


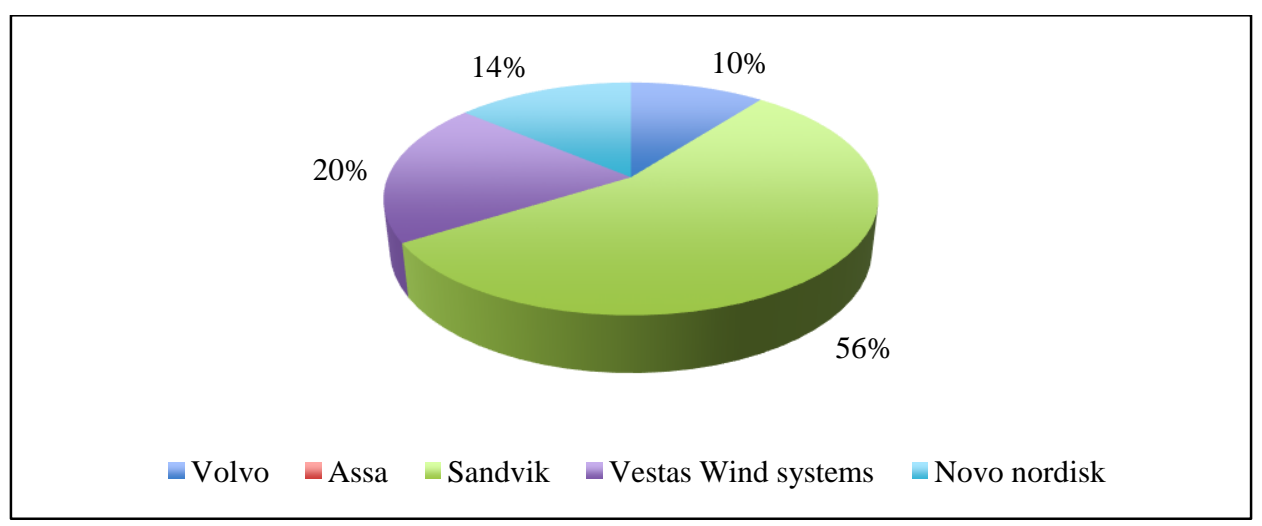

2 paveikslas. Optimalus investicinis portfelis pagal Black - Litterman modeli (sudaryta autoriaus)

Iš 2 paveiksle pateiktų duomenų, matome, kad daugiau nei puse portfelio sudaro „Sandvik“ imonès akcijos (55,65 proc.), mažiausią dalị sudaro „Volvo“ akcijos (10,48 proc.), i portfeli nepateko „Assa“ imonès akcijos. Sudaryto optimalaus portfelio pelningumas siekia 0,096 proc., portfelio rizika siekia 0,015 proc. Palyginimui sudarytas investicinis portfelis remiantis Harry Markowitz optimalaus portfelio teorija (žr. 3 paveikslą).

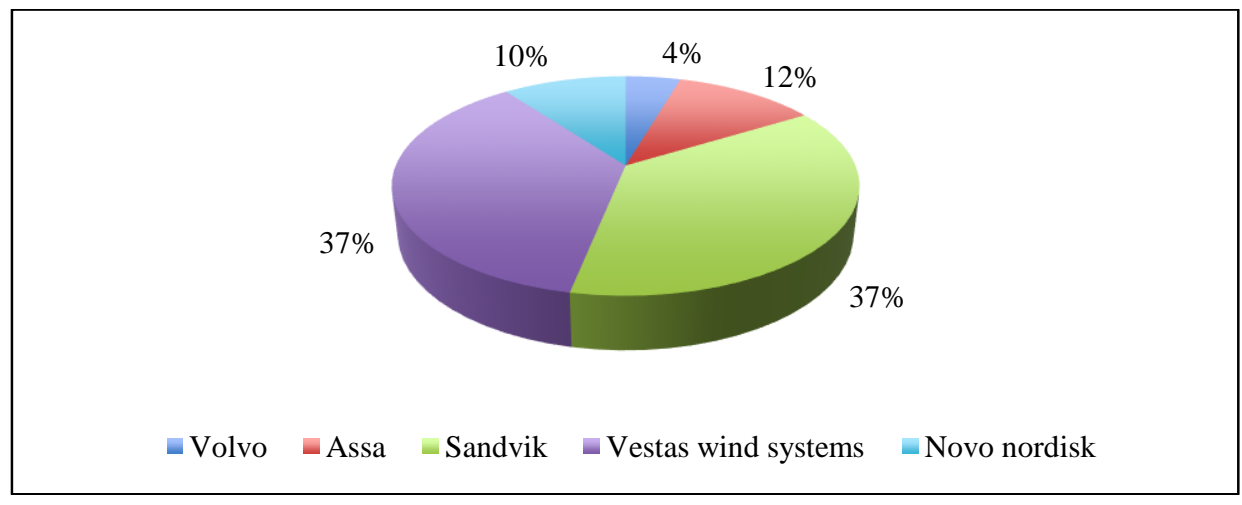

3 paveikslas. Optimalus investicinis portfelis pagal H. Markowitz modelị (sudaryta autoriaus)

Didžiają investicinio portfelio sudaryto pagal H. Markowitz modelį dalį sudaro „Vestas wind system“ (36,61 proc.) ir „Sandvik“ (36,9 proc.), mažiausią dalị sudaro „Volvo“ imonès akcijos (4,53 proc.), sudaryto portfelio grąža siekia 0,083 proc., rizika 0,013 proc.

Lyginant sudarytus portfelius, galima pastebèti, jog jų sudètis kardinaliai skiriasi: pagal BL sudarytame portfelyje didžiają dali akcijų sudaro „Sandvik“ įmonés akcijos, H Markowitz portfelyje didžiają dali sudaro „Vestas wind systems“ ir „Sandvik“ įmonių akcijos, mažiausią dalị abiejuose portfeliuose sudaro „Volvo" ịmonès akcijos, tačiau ị BL portfelį nebuvo įtrauktos „Assa“ i̇monès akcijos, kurios Markowitz portfelyje sudaro 11,75 proc. Lyginant laukiamus portfelių rezultatus, didesnè grąža laukiama iš BL portfelio 0,96 proc., su sąlyginai nedidele 0,015 proc. rizika.

\section{Išvados}

Siekiant patobulinti H. Markowitz optimalaus portfelio teoriją, buvo sukurta Black - Litterman teorija, kurios pagrindu ir išskirtinumu tampa akcijų kainu grąžu sujungimas su investuotojo subjektyviu požiūriu ị vertybinius popierius. Ši teorijos naujove gali padèti ịvertinti vertybinių popieriu pokyčius, nepriklausant vien tik nuo istoriniu kainu pokyčių, kurie ne visada yra tikslus, nes tikima, jog vertybinių popieriu kainos rinkoje yra neteisingai nustatytos, todèl investuotojai pasitelkę savo nuomonę, gali atrasti per mažai ịvertintus vertybinius popierius, kuriuos gali ịtraukti ị investicini portfeli.

Black - Litterman modelyje taip pat pateikiamas naujas grąžos matas - laukiama perteklinė grąža, rizikai matuoti naudojamas polinkio ị riziką parametras, kuris padeda ịvertinti kaip investuotojai nusiteikę rizikuoti. Lyginant Black - Litterman ir H. Markowitz teorijas, galima išskirti du pagrindinius Black - Litterman teorijos privalumus: investuotojo individualaus požiūrio ịtraukimą i modelį, ir tai, jog BL modelis yra ne toks jautrus duomenų pokyčiams, būtent dèl šių dviejų aspektų yra labiausiai kritikuojamas H. Markowitz modelis. Pagrindiniais Black - Litterman teorijos trūkumais tampa sudètingi skaičiavimai, vertinimo parametrų neapibrèžtumas, kuris išlieka pagrindiniu mokslininkų ginčų objektu ir teorijos parėmimas abejotinomis rinkos prielaidomis. 
Tačiau, galima daryti prielaidą, jog Black - Litterman teorija yra tobulesnè H. Markowitz teorijos versija, kuri papildo pirmtaką.

Investicinio portfelio formavimui pasirinktos įmonès iš „OMX Nordic 40“ indekso, kurios vertinamos pagal finansinius rodiklius. Remiantis AHP rezultatais, atliekamas daugiakriterinis vertinimas TOPSIS metodu, kurio metu pasirenkamos penkios perspektyviausios įmonès investavimui: Volvo“, „Assa“, „Sandvik“, „Novo nordisk“ ir „Vestas wind systems“, kuriomis bus formuojamas optimalus investicinis portfelis pagal Black - Litterman ir H. Markowitz teorijas.

Lyginant sudarytus optimalius investicinius portfelius, BL portfelis, kuri sudaro „Sandvik“ (55,64 proc.), „Vestas wind systems“ (20 proc.), „Novo nordisk“ (13,87 proc.) ir „Volvo“ (10,48 proc.) įmonių akcijos, portfelio laukiama grąža siekia 0,096 proc., rizika - 0,015 proc., pelningesnis ir sąlyginai mažiau rizikingas, nei H. Markowitz, kurio grąža siekia 0,083 proc., rizika - 0,013 proc. Darant prielaidą, kad investuotojo požiūris i įmonių akcijų kainų pokyčius yra teisingas, atsižvelgiant ị teorinius modelių aspektus, galima daryti išvadą, jog Black- Litterman optimalaus investicinio portfelio teorija yra pranašesnė už H. Markowitz optimalaus investicinio portfelio teoriją.

\section{Literatūra}

Aires, R. F. de F., \& Ferreira, L. (2019). A new approach to avoid rank reversal cases in the TOPSIS method. Computers and Industrial Engineering, 132, 84-97. https://doi.org/10.1016/j.cie.2019.04.023

Allaj, E. (2017). The Black-Litterman model and views from a reverse optimization procedure: an out-of-sample performance evaluation. SSRN Electronic Journal. https://doi.org/10.2139/ssrn.2999335

Bayram, K., Abdullah, A., \& Meera, A. K. (2018). Identifying the optimal level of gold as a reserve asset using BlackLitterman model. International Journal of Islamic and Middle Eastern Finance and Management, 11(3), 334-356. https://doi.org/10.1108/IMEFM-06-2017-0142

Biswas, P., Pramanik, S., \& Giri, C. (2015). TOPSIS method for multi-attribute group decision-making under single-valued neutrosophic environment. Neural Computing and Applications, 27(3), 11. https://doi.org/10.1007/s00521-015-1891-2

Brazauskas, M. (2014). Ekonomika ir vadyba: aktualijos ir perspektyvos. Šiauliai. https://etalpykla.lituanistikadb.lt/object/LT-LDB-0001:J.04 2014 1473065449733/J.04 2014 1473065449733.pdf

Cayirli, O. (2019). The Black-Litterman model: extensions and asset allocation. SSRN Electronic Journal. https://doi.org/10.2139/ssrn.3464770

Chen, P. (2019). Effects of normalization on the entropy-based TOPSIS method. Expert Systems with Applications, 136, 3341. https://doi.org/10.1016/j.eswa.2019.06.035

Dash, R., Samal, S., Dash, R., \& Rautray, R. (2019). An integrated TOPSIS crow search based classifier ensemble: In application to stock index price movement prediction. Applied Soft Computing Journal, 85, 105784. https://doi.org/10.1016/j.asoc.2019.105784

Gharakhani, M., \& Sadjadi, S. J. (2013). A fuzzy compromise programming approach for the Black-Litterman portfolio selection model. Decision Science Letters, 2(1), 11-22. https://doi.org/10.5267/j.dsl.2012.12.001

Huang, X., \& Yang, T. (2020). How does background risk affect portfolio choice: An analysis based on uncertain meanvariance model with background risk. Journal of Banking and Finance, 111. https://doi.org/10.1016/j.jbankfin.2019.105726

Idzorek, T. (2007). A step-by-step guide to the Black-Litterman model: Incorporating user-specified confidence levels. In Forecasting Expected Returns in the Financial Markets (pp. 17-38). Elsevier Ltd. https://doi.org/10.1016/B978-075068321-0.50003-0

Jurkonytė, E. ir Paužuolis, V. (2015). Moderniosios, postmoderniosios portfelio teorijų ir Black-Litterman modelio palyginimas. Mokslo Taikomieji Tyrimai Lietuvos Kolegijose, 1(11), 7. http://ojs.kaunokolegija.lt/index.php/mttlk/article/view/16

Khan, A. A., Shameem, M., Kumar, R. R., Hussain, S., \& Yan, X. (2019). Fuzzy AHP based prioritization and taxonomy of software process improvement success factors in global software development. Applied Soft Computing Journal, 83. https://doi.org/10.1016/j.asoc.2019.105648

Kolios, A., Mytilinou, V., Lozano-Minguez, E., \& Salonitis, K. (2016). A comparative study of multiple-criteria decisionmaking methods under stochastic inputs. Energies, 9(7), 566. https://doi.org/10.3390/en9070566

Li, B., Sun, Y., Aw, G., \& Teo, K. L. (2019). Uncertain portfolio optimization problem under a minimax risk measure. Applied Mathematical Modelling, 76, 274-281. https://doi.org/10.1016/J.APM.2019.06.019

Mannan, B., \& Haleem, A. (2017). Understanding major dimensions and determinants that help in diffusion \& adoption of product innovation: using AHP approach. Journal of Global Entrepreneurship Research, 7(1). https://doi.org/10.1186/s40497-017-0072-4

Norell, J., \& Dove, E. (2016). Black-Litterman portfolio allocation stability and financial performance with MGARCH-M derived views. https://lup.lub.lu.se/student-papers/search/publication/8881134

Palczewski, A., \& Palczewski, J. (2019). Black-Litterman model for continuous distributions. European Journal of Operational Research, 273(2), 708-720. https://doi.org/10.1016/j.ejor.2018.08.013

Palczewski, K., \& Sałabun, W. (2019). The fuzzy TOPSIS applications in the last decade. Procedia Computer Science, 159, 2294-2303. https://doi.org/10.1016/j.procs.2019.09.404 
Pang, T., \& Karan, C. (2018). A closed-form solution of the Black-Litterman model with conditional value at risk. Operations Research Letters, 46(1), 103-108. https://doi.org/10.1016/J.ORL.2017.11.014

Polovenko, T. (2017). Black-Litterman model. Viena. https://fam.tuwien.ac.at/ sgerhold/pub_files/sem16/s_polovenko.pdf

Rajak, M., \& Shaw, K. (2019). Evaluation and selection of mobile health (mHealth) applications using AHP and fuzzy TOPSIS. Technology in Society, 59, 101186. https://doi.org/10.1016/j.techsoc.2019.101186

Silva, T., Pinheiro, P. R., \& Poggi, M. (2017). A more human-like portfolio optimization approach. European Journal of Operational Research, 256(1), 252-260. https://doi.org/10.1016/j.ejor.2016.06.018

Simanavičienè, R. ir Cibulskaite, J. (2015). Sprendimo, gauto TOPSIS metodu, patikimumo statistinè analizè. Lithanian Journal of Statistics, 54, 9.

Solangi, Y. A., Tan, Q., Mirjat, N. H., \& Ali, S. (2019). Evaluating the strategies for sustainable energy planning in Pakistan: An integrated SWOT-AHP and Fuzzy-TOPSIS approach. Journal of Cleaner Production, 236. https://doi.org/10.1016/j.jclepro.2019.117655

Subekti, R., Ratna Sari, E., \& Kusumawati, R. (2019). Combining Black-Litterman model with clustering on portfolio construction. Journal of Physics: Conference Series, 1321(2), 1-6. https://doi.org/10.1088/1742-6596/1321/2/022051

Trichilli, Y., Abbes, M. B., \& Masmoudi, A. (2020). Islamic and conventional portfolios optimization under investor sentiment states: Bayesian vs Markowitz portfolio analysis. Research in International Business and Finance, 51. https://doi.org/10.1016/j.ribaf.2019.101071

Vilkancas, R. (2017). Kintamos slenkstinès gražos poveikio omega funkcijos atžvilgiu optimizuotiems investiciju portfeliams tyrimas. Technika. https://doi.org/10.20334/2017-030-M

Wang, B., Xie, H. L., Ren, H. Y., Li, X., Chen, L., \& Wu, B. C. (2019). Application of AHP, TOPSIS, and TFNs to plant selection for phytoremediation of petroleum-contaminated soils in shale gas and oil fields. Journal of Cleaner Production, 233, 13-22. https://doi.org/10.1016/j.jclepro.2019.05.301

Zakarkaite, A. ir Filipavičius, V. (2017). H. Markowitz'o modelio tinkamumo Baltijos vertybinių popierių biržai tikrinimas. In Proceedings of the $20^{\text {th }}$ Conference for Junior Researchers „Business in XXI Century“ (p. 9). Vilnius. https://doi.org/10.3846/vvf.2017.021

\title{
INVESTMENT PORTFOLIO FORMATION IN GLOBAL STOCK MARKET, BASED ON BLACK - LITTERMAN METHOD
}

\section{Laurynas MIKULIS, Renaldas VILKANCAS}

\begin{abstract}
The article analyses Black - Litterman optimal portfolio theory and it's practical application. Based on the analysis of literature, Black - Litterman theory defined and compared to H. Markowitz theory, excreted main advantages and disadvantages of BL theory. The analityical hierarchical process (AHP) determines the weights of the selected financial ratios. By using TOPSIS multi - criteria method, among the ten largest companies in the "OMX Nordic 40" index: "OMX Nordic 40" indekse: "Volvo", “Assa", "Sandvik", "Neste", "Investor", "SEB", “Atlas", "Novo Nordisk", "Vestas wind systems", and "Nordea”, five most promising companies equities are selected for investment. Based on the obtained results, the optimal investment portfolio is formed according to Black - Litterman and H. Markowitz models, results of the portfolio are evalueated and compared with each other.
\end{abstract}

Keywords: portfolio optimization, Black - Litterman, investor views, "OMX Nordic 40", TOPSIS, AHP, H. Markowitz. 